potassium. As Hodgkin points out, although the loss for each impulse in the giant nerve fibre of the squid is only a millionth of the total internal potassium, in the very fine dendrites of the central nervous system the internal store would fall much more rapidly if it were not replenished. Where continuous activity is the rule, as in the controlling regions of the central nervous system, there may well be considerable fluctuations in the internal levels of potassium and sodium ions which may have a profound effect on the working of the cells and about which we are still completely ignorant.

This attack at the biophysical level is beginning to reduce the problems of cell organization in the nervous system to the molecular level. It is likely to explain many of the characteristic properties of nervous tissue, and certainly a clear picture of the cell mechanism must be the basis for any picture of the nervous system as a whole. But the title of Sherrington's book reminds us that most of the picture is very far from clear. The cell units are there to give the integrative action of the whole animal, and we have to find out how they are organized into the nervous system as well as how each one stores and discharges ions.

The problem of organization is partly anatomicaldeciding what each fibre tract and cell mass contributes to the total activity. Here there has been and will be a steady advance. But the special feature of the nervous system is the wide variety of action it controls and its power to make behaviour appropriate to future as well as to present needs. It is, in fact, the great diversity of its interests which makes it so difficult to proceed.

Since we are still searching for the physical changes which accompany learning, the changes-structural or molecular-which make the nervous system react differently after training, there is little as yet to bridge the gap between the biophysics of the nerve cell and the fully elaborated activity of the whole system. If we could find, for example, the cell changes which establish a conditioned reflex, we should still have only the general principles of nervous organization. We could not forecast in detail how any particular nervous system would react unless we knew every detail of its past history.

The sort of difficulty which confronts us in studying the organization of the brain is illustrated by recent work which aims at plotting by electrical methods the more remote consequences of the arrival of a sensory message in the brain. Lilly in the United States and Grey Walter in Britain have already made some very interesting observations by different techniques; but to describe their results adequately is already a considerable feat, involving the reduction of fourdimensional patterns to a two-dimensional page.

To understand the integrative action of the nervous system we have to relate the unit to the whole system and the system to the work it has to do. The study of the unit is advancing rapidly, though it is mostly concerned with the immediate response to stimulation and we know little about slower and more persistent effects. When we do know more, it may be that the general plan on which the units are organized will become much clearer. Perhaps a complete revision of outlook may be necessary. At all events there is no need to be pessimistic. There is a wealth of new material and new methods, and a branch of natural science is in a healthy state when it has advanced to the stage where its traditional conceptions begin to look inadequate.

\section{BIOLOGY OF DESERTS}

A SYMPOSIUM on "The Biology and ProA ductivity of Hot and Cold Deserts', organized by the Institute of Biology, was held at the Royal Institution during September 25-27. It consisted of six sessions devoted to various aspects of desert biology : climate and physical environment; plant ecology ; entomology and ecology ; economic aspects ; and mammalian physiology and ecology.

Dr. Edward Hindle, president of the Institute, in an opening speech in which he welcomed delegates from abroad, mentioned that the United Nations Educational, Scientific and Cultural Organization showed a special interest in the symposium and contributed towards the expenses of speakers from overseas. Brigadier R. A. Bagnold (the well-known desert explorer) then communicated an introductory paper on the geography of deserts by Prof. Frank Debenham (formerly professor of geography in the University of Cambridgè), who was not able to attend in person, and read his own paper on the physical aspects of dry deserts. In the first of these papers, it was pointed out that the distribution of deserts in the world is due mainly to the circulation of the atmosphere, particularly in its lower layers, whereby certain areas are starved of moisture. In addition, many local factors affect the intensity of desert conditions, and excessive insolation by day tends to produce extreme instability in the rainfall. Brigadier Bagnold then said that this intermittent precipitation is variable not only in time but also in place, and only by nomadic wandering over large areas can its effect be exploited. If nomadism were prevented for political reasons, much of the desert would become totally unproductive. Prof. F. W. Shotton (University of Birmingham) emphasized the salinity of most underground desert waters, which are consequently unsuitable for irrigation. Although in semi-desert areas such as southern Palestine considerable development of underground waters can still be hoped for, the prospect for the greater part of the true deserts must always be poor. Dr. C. B. Williams (Rothamsted Experimental Station) then described three studies of microclimatic conditions made some years ago at Wadi Digla in the hilly desert near Cairo. Great variations in conditions occurred between localities only a few feet apart, particularly during the summer; but twelve metres within a cave the daily and seasonal range of temperature was only 2 deg. C. Thus by moving a very short distance, animals can escape extremes of heat and have a wide range of conditions at their disposal. In the discussion that followed, Prof. J. A. Prescott (Waite Agricultural Research Institute and University of Adelaide) pointed out that the variable and local nature of the rainfall in northern Australia has long been realized by pastoralists whose cattle, unhindered by fences, travel great distances to favourable areas, and Dr. H. Greene (Rothamsted Experimental Station) suggested that, although the violent spates of water in the wadis of the Sudan carry so much sediment that storage by dams is impracticable, the deposition of this as silt results in a natural rotation of the soil.

Dr. Hugo Boyko (chief ecologist to the Ministry of Agriculture, Israel) opened the second session with an account of the main lines of plant ecological research that are being carried out in his country. These include pasture problems and the effect of grazing, searching for food plants adapted to desert con- 
ditions and for plant raw materials, and the application to biology of other branches of science such as climatology, hydrology and hydro-engineering. A paper by Prof. Th. Monod (director of the Institut Français d'Afrique Noire) outlined the distribution of the basic contracted and diffuse types of vegetation in the Sahara, and Prof. R. D'O. Good (University College, Hull) gave an account of the desert flora of the arid Bahrain Islands in the Persian Gulf. These islands are of interest in that they illustrate with peculiar clarity, and within a circumscribed area, many of the characteristic features of deserts in general. Prof. M. Zohary (Hebrew University, Jerusalem) then presented an analysis of the many hydro-economic types of vegetation occurring in the Near East deserts, and a paper by Prof. $I$. Reichart (Jerusalem), crediting xerothermic climates with the suppression of many pathogenic bacteria and downy mildews, was followed by a general discussion.

In the third session an exposition of phytosociological research carried out in French North Africa to provide a rational basis for the evaluation of the soil was given by Prof. L. Emberger (Montpellier). At Montpellier and Zurich a cartographical method has been devised to demonstrate vegetational associations which directly indicate the nature of the underlying rock, and similar surveys are now being carried out in central Tunisia and western Algeria. The secretary-general of the International Union of Biological Sciences, Prof. P. E. L. Vayssière, then described how modern methods of rapid travel have, in a number of cases, transported pests of such economic plants as dates and cotton across natural barriers of arid desert, and introduced them into oases and other areas from which they had previously been absent. Dr. B. P. Uvarov (director of the AntiLocust Research Centre, London) gave a warning that desert irrigation schemes may increase the danger of locust infestation in other areas by providing new permanent breeding-grounds. The desert locust requires adequate soil moisture before it can increase in numbers to the point of swarming, and, both at Abyan near Aden and at Tokr on the Sudan coast, irrigation schemes have already resulted in a semi-permanent population of desert locusts. Dr. A. S. Balachowsky (Institut Pasteur) gave an account of the problems of applied entomology in the Sahara, with particular reference to the biology of indigenous species that have become adapted to feed upon cultivated plants. This was followed by a description by Prof. F. Bernard (Algiers) of the economic importance of social insects, particularly termites and ants, in the desert. Methods were suggested for encouraging useful, and for reducing harmful, species.

The microbiological formation of sulphur in Cyrenaican lakes, particularly Ain-ez-Zauia, was the subject of a joint paper by K. R. Butlin and J. R. Postgate, who led an expedition from the Chemical Research Laboratory, Teddington, to the area in 1950 , and methods of increasing the yield were discussed. Prof. E. P. Stebbing (formerly professor of forestry in the University of Edinburgh) emphasized that the man-made desert is a stern reality ; man has been the enemy of forests since earliest times, and large-scale clearing has resulted in erosion and the production of arid regions. Dr. S. M. Manton (King's College, London) then gave an outline of the large irrigation and development schemes being carried out in Central Asia, and of the biological research associated with the construction of the Turkmenian canal and the development of the Kara Kum desert.
She was followed by Prof. J. F. V. Phillips (Achimota, Gold Coast), who discussed aspects of the ecology and productivity of the arid regions in southern and eastern Africa. The deserts themselves are of little potential productive importance, but their significance in regard to possible encroachment is profound. Mismanagement by most African and many European farmers, he said, is increasing the desiccation of the land at an alarming rate. Emphasis was laid on the role of the tsetse fly in controlling tou rapid a development and on the agencies responsible for increased erosion. From experience gained while associated with the Groundnuts Scheme, Prof. Phillips gave warning of the far-reaching repercussions of insufficiently planned attempts to clear large areas of natural vegetation within a short time, and advocated ecological surveys and pilot schemes extending over at least five years. In the discussion that followed, the damaging effect of clearing forest by fire was contested by Dr. A. S. Thomas (London).

Sessions on the last day were devoted to problems of mammalian physiology and ecology. Prof. F. S. Bodenheimer (Hebrew University, Jerusalem) described research on the seasonal cycle of the gonads and endocrine glands in gazelles and camels, carried out in his laboratory at Jerusalem. This cycle is adapted to the seasonal rainfall, with the result that the young are born when vegetation is most abundant. Dr. Norman C. Wright (scientific adviser to the Ministry of Food) compared the morphology of domesticated animals inhabiting hot and cold deserts, in contrast to that of animals from non-desert areas. The majority of the former are slightly sweating species that employ polypnea as a temperature defence mechanism. Solar radiation is reduced by various protective devices which were discussed from the point of view of the histology of the skin, the hair characteristics and behaviour reactions. Suitable fodder may help to alleviate the gross heat burden. Water conservation in kangaroo-rats and pocket mice was discussed by Dr. Bodil Schmidt-Nielsen (Cincinnati), who has investigated the physiology of the desert rodents in Arizona. She found that these animals never drink, but obtain an amount of water equal to more than half the weight of the dry seeds which form their staple diet by oxidizing this food within their bodies. Evaporation from the respiratory tract is relatively small because of the low temperature of the respired air, the urine is very concentrated and the fæces contain less water than that of most mammals. The subject of heat regulation in these animals was mentioned by Dr. Knut SchmidtNielsen, who said that the loss of water by evaporation is avoided by living in burrows during the day and emerging only at night. If a kangaroo-rat is exposed to great heat, the fur of its throat becomes moistened with saliva, but even by this means it cannot survive for more than twenty minutes. Although the areas covered by bluebush in southern Australia have been greatly depleted during the past century, Prof. H. C. Trumble and Mr. K. Woodroffe (University of Adelaide) found that properly controlled grazing, pruning of older bushes and seedling establishment by reduction of competition for moisture from annual species could induce a general improvement. Problems of water conservation and of adaptive coloration formed the principal topics of the discussion which followed.

In the final session, Dr. J. S. Weiner (Oxford) discussed human adaptability to high temperatures 
and suggested that the function of the skin pigment in the Negro is primarily to protect the sweat glands from injury by excessive ultra-violet light. Dr. Frank Marsh (London) then described experiments on rabbits subjected to great environmental heat, which threw light on the treatment of human heat-stroke, and a paper was given by Dr. Edmond Sergent (director of the Institut Pasteur d'Algérie) on the problems of populating the Sahara: he postulated that white families could never become acclimatized there as the heat is too great for the women and children, black races would find the winters too cold, and the nomads, who are camel owners, shepherds and warriors, are useless at manual work; consequently, only the indigenous negroid race could usefully multiply, and only in proportion to the amount of water available. Dr. O. G. Edholm (London) described the physiological effects of cold environment on man. He said that although acclimatization to cold occurs, it is a relatively slow process, and suggested that, in fact, man has probably evolved as a tropical animal.
Sir David Brunt (formerly of the Imperial College of Science and Technology) showed by means of graphs the conditions in which office work can be carried on in the afternoon in tropical climates. The limitation appears to fall within a well-defined range of temperature and humidity.

After the discussion, Dr. Frank Malina spoke on behalf of Unesco, and Prof. J. F. Danielli (King's College, London), honorary secretary of the Institute of Biology, summed up. The latter said that, from the papers presented at the symposium, it was apparent that individual deserts present a multitude of different problems. Scientific investigation must precede development; but in most cases the major difficulties are social, moral and political, and present problems of ethics rather than of science.

The proceedings of the symposium will be published by the Institute of Biology, Tavistock House South, W.C.l. Prof. R. D'O. Good has very kindly

read through this article in manuscript.
J. L. CLOUDSLEY-THOMPSON read through this article in manuscript.
J. L. CLOUDSLEY-THOMPson

\section{NEWS}

\section{Mechanical Engineering in Manchester:}

Prof. Jack Diamond

THe Council of the University of Manchester has announced the appointment of Mr. Jack Diamond to the first chair of mechanical engineering in the Faculty of Science. This is additional to the Beyer chair (founded in 1868 and first held by Osborne Reynolds) and the chair of electro-technics (1912). In addition there are also, in the Faculty of Technology, chairs in both mechanical and electrical engineering, established when that Faculty was established in the Manchester College of Technology in 1905.

Mr. Diamond's early training was followed by an apprenticeship at H.M. Dockyard School, Chatham, from which he proceeded to the City and Guilds College, London, as a Whitworth Scholar in 1932. In 1935 he was awarded first-class honours in mechanical engineering and was elected to a Senior Whitworth Scholarship. This he held for the next two years at St. John's College, Cambridge, where he undertook research in heat transfer; he was awarded the degree of M.Sc. in 1937. Mr. Diamond was then appointed a demonstrator in mechanical sciences in the University of Cambridge and a supervisor in St. John's College, resigning in 1939 on taking a temporary commission as an engineer officer in the Royal Navy. Three years later he was appointed assistant to the Engineer Manager of Rosyth Dockyard and, after becoming a temporary lieutenantcommander (E.), retired from the service in 1944 to become a senior scientific officer in the British Atomic Energy Team at Montreal. Since 1946, he has been a senior principal scientific officer at the Atomic Energy Research Establishment at Harwell, working on the design and development of nuclear reactors and on associated heat-transfer problems.

Seventieth Birthday Anniversaries: Profs. J. Franck and $M$. Born

ON August 26, 1952, Prof. James Franck, the director of the Fels Fund research in the University of Chicago, and formerly of Göttingen and the Johns Hopkins University, celebrated his seventieth birthday. A tribute in honour of his birthday appears in the July number of the Reviews of Modern Physics

\section{nd VIEW S}

$(24,117 ; 1952)$. It is contributed by Prof. Peter Pringsheim, of the Argonne National Laboratory, Chicago, and consists of a short biographical article describing briefly Franck's numerous scientific achievements. Born in Hamburg, Franck studied chemistry in Hamburg and Berlin, and was appointed in 1920 to the chair of physics at Göttingen. During the thirteen years that followed, Göttingen became under Franck's direction one of the most important centres of research in atomic and molecular physics, a happy and brilliant period which was brought to an abrupt end when Hitler assumed power in Germany. Throughout his whole career, Prof. Franck's work has been characterized by a simplicity in experimental apparatus and principle: the wellknown Franck-Condon principle is but an application of the law of conservation of momentum, and the Franck-Hertz experiment of 1914, for which Franck obtained the Nobel Prize a few years later, was a straightforward experimental confirmation of Bohr's atomic theory. The study of fluorescence has been Franck's main occupation, and from that he has been led more recently into the important field of research in photosynthesis. Finally, Prof. Pringsheim singles out for special mention Franck's two outstanding qualities, his obsession for science and his inexhaustible kindness. As a further tribute and one emanating from Göttingen itself, Profs. M. von Laue and R. W. Pohl, the editors of the Zeitschrift für Physik, have collected together in the number for September 15 $(133,1 ; 1952)$ a series of articles specially contributed by colleagues and friends of Prof. Franck and of Prof. Max Born, of the University of Edinburgh, who also celebrates his seventieth birthday this year, on December 11. Most of the articles are in German, but several are in English.

\section{The Pharmaceutical Society: Hanbury Memorial Medal}

THE Pharmaceutical Society has awarded the Hanbury Memorial Medal to Prof. Gösta Edman, professor of botany and pharmacognosy in the Royal Pharmaceutical Institute, Stockholm. This Medal is given periodically for "high excellence in the prosecution or promotion of original research in the Natural 